\title{
Flagellin Is Not a Major Defense Elicitor in Ralstonia solanacearum Cells or Extracts Applied to Arabidopsis thaliana
}

\author{
Christine Pfund, ${ }^{1}$ Julie Tans-Kersten, ${ }^{1}$ F. Mark Dunning, ${ }^{1}$ Jose M. Alonso, ${ }^{3}$ Joseph R. Ecker, ${ }^{3}$ \\ Caitilyn Allen, ${ }^{1}$ and Andrew F. Bent ${ }^{1,2}$
}

'Department of Plant Pathology, ${ }^{2}$ Program in Cell and Molecular Biology, University of Wisconsin, Madison, 1630 Linden Drive, Madison, WI 53706, U.S.A.; ${ }^{3}$ Salk Institute Genomic Analysis Laboratory, The Salk Institute for Biological Studies, La Jolla, CA 92037, U.S.A.

Submitted 13 June 2003. Accepted 2 March 2004.

\begin{abstract}
The phytopathogenic bacterium Ralstonia solanacearum requires motility for full virulence, and its flagellin is a candidate pathogen-associated molecular pattern that may elicit plant defenses. Boiled extracts from $R$. solanacearum contained a strong elicitor of defense-associated responses. However, $R$. solanacearum flagellin is not this elicitor, because extracts from wild-type bacteria and $f l i C$ or $f l h D C$ mutants defective in flagellin production all elicited similar plant responses. Equally important, live $R$. solanacearum caused similar disease on Arabidopsis ecotype Col-0, regardless of the presence of flagellin in the bacterium or the FLS2-mediated flagellin recognition system in the plant. Unlike the previously studied flg22 flagellin peptide, a peptide based on the corresponding conserved $\mathrm{N}$-terminal segment of $R$. solanacearum, flagellin did not elicit any response from Arabidopsis seedlings. Thus recognition of flagellin plays no readily apparent role in this pathosystem. Flagellin also was not the primary elicitor of responses in tobacco. The primary eliciting activity in boiled $R$. solanacearum extracts applied to Arabidopsis was attributable to one or more proteins other than flagellin, including species purifying at approximately 5 to $10 \mathrm{kDa}$ and also at larger molecular masses, possibly due to aggregation. Production of this eliciting activity did not require $h r p B$ (positive regulator of type III secretion), pehR (positive regulator of polygalacturonase production and motility), gspM (general secretion pathway), or phcA (LysR-type global virulence regulator). Wild-type $R$. solanacearum was virulent on Arabidopsis despite the presence of this elicitor in pathogen extracts.
\end{abstract}

Swimming motility, mediated by extracellular flagella, allows bacteria to move in response to their environment (Moens and Vanderleyden 1996). The structural components of flagella include a basal body capable of rotary motion, a hook apparatus, and thousands of flagellin monomers that polymerize to form the flagellar filament (Schuster and Khan

\footnotetext{
C. Pfund and J Tans-Kersten contributed equally to this work.

C. Allen and A. F Bent contributed equally to this work.
}

Corresponding author: A. F. Bent, E-mail: afb@ plantpath.wisc.edu; Telephone: 1.608.265.3075.

Current address for J. M. Alonso: Department of Genetics, North Carolina State University, Raleigh, NC 27695. U.S.A.
1994). Polymerization is facilitated by conserved domains near both the $\mathrm{N}$ - and $\mathrm{C}$-termini of each flagellin protein, while the central domain is hypervariable (Wilson and Beveridge 1993). In addition to its role in motility, flagellin is a known elicitor of animal innate immune responses mediated by tolllike receptors (Aderem 2001; Imler and Hoffmann 2001; Jacchieri 2003; Khush and Lemaitre 2000; Kopp and Ghosh 1994; Sieling and Modlin 2002). Flagellin can also elicit defense responses in plants. A series of studies with plant pathogenic and nonpathogenic bacteria have demonstrated that flagellin contains pathogen-associated molecular patterns that can be recognized by some plants, leading to activation of defense responses to counter pathogen attack (Che et al. 2000; Felix et al. 1999; Gomez-Gomez and Boller 2002). However, host plant perception of flagellin has not been shown to successfully limit bacterial growth or disease damage in plants.

We have investigated the role of motility in Ralstonia solanacearum. $R$. solanacearum is the causal agent of bacterial wilt, a vascular disease that affects over 50 families of plants worldwide, including tomato, potato, tobacco, banana, and plantain. This soil-borne disease causes substantial crop losses in the tropics and subtropics, resulting in great economic and human hardship (Hayward 1991). Nonmotile mutants of $R$. solanacearum are significantly reduced in virulence on tomato plants, indicating that motility plays an important role (TansKersten et al. 2001). $R$. solanacearum mutants lacking flagella caused reduced disease in a naturalistic soil soak inoculation assay that requires the bacteria to find and invade plant roots from the soil but caused wild-type levels of disease when introduced directly into the plant vasculature (Tans-Kersten et al. 2001). This suggests that motility plays a role early in infection and colonization. In several animal host systems, bacterial motility has been shown to be an important virulence factor mediating adhesion, invasion, and colonization (Giron et al. 2002; Ottemann and Lowenthal 2002; Tomich et al. 2002; Young et al. 2000).

As motility contributes to virulence and flagella are readily apparent on the bacterial cell surface, it is reasonable that plants might have evolved means to perceive flagella and subsequently activate defense mechanisms. However, this type of activity would have to be carefully balanced, because unnecessary defense activation in response to benign or beneficial bacteria would be likely to carry selective penalties. The discovery of flagellin perception by plants originated from the observation that many phytopathogenic bacteria can trigger an oxidative burst in the host when added to suspension-cultured plant cells 
(Felix et al. 1999; Gomez-Gomez and Boller 2002). The oxidative burst is an indicator of defense activation in plants (Baker and Orlandi 1995; Doke 1983). Bacterial extracts from Pseudomonas syringae pv. tabaci were most effective at eliciting an oxidative burst when they were heat-denatured by boiling (Felix et al. 1999). Biochemical analysis of these boiled extracts demonstrated that flagellin was the major protein responsible for eliciting an oxidative burst in tomato suspension culture cells (Felix et al. 1999). FIg22, a 22-amino acid peptide derived from a conserved domain in the $\mathrm{N}$-terminus of many flagellins, is sufficient for elicitation of the oxidative burst in tomato, tobacco, potato, and Arabidopsis suspension-culture cells and may serve as a pathogen-associated molecular pattern for certain plants (Felix et al. 1999). Similar f1g22 peptides based on flagellins from a wide range of gram-negative bacteria, including some phytopathogens, elicited a response. However, Agrobacteriumand Rhizobium-based peptides were inactive (Felix et al. 1999). $R$. solanacearum sequences apparently were not tested.

In Arabidopsis seedlings, f1g22 peptide can elicit rapid defense-associated responses such as callose deposition, an oxidative burst, and induction of pathogenesis-related (PR) gene expression (Felix et al. 1999; Gomez-Gomez et al. 1999). These defense responses are associated with a measurable inhibition of seedling growth upon prolonged treatment with f1g22 (Gomez-Gomez et al. 1999). Importantly, recognition of fIg22 has been attributed to the leucine-rich repeat (LRR) receptor-like kinase FLS2, as Arabidopsis lines carrying a mutated version of this receptor fail to respond to flg22 (GomezGomez and Boller 2000). Additional studies of FLS2 have suggested that f1g22 may bind directly to FLS2 and have identified a kinase cascade that functions downstream of FLS2 (Asai et al. 2002; Bauer et al. 2001; Gomez-Gomez and Boller 2002; Gomez-Gomez et al. 2001).

We sought to investigate the role of $R$. solanacearum flagellin in the elicitation of defense in Arabidopsis. We hypothesized that boiled extracts from $R$. solanacearum would elicit defense-associated responses in plants and that $R$. solanacearum strains lacking flagellin would not induce these responses. We further hypothesized that bacterial strains able to elude detection by the plant's flagellin-recognition system would have enhanced virulence. To test these hypotheses, we measured Arabidopsis seedling responses to boiled extracts from flagellate and aflagellate $R$. solanacearum strains and to a f1g22 peptide based upon $R$. solanacearum flagellin. We detected one or more defense-eliciting proteins in boiled extracts of $R$. solanacearum. However, flagellin and the host FLS2 receptor were neither associated with response elicitation nor with overall reduction of virulence.

\section{RESULTS}

Extracts from aflagellate $R$. solanacearum strains elicit a defense response in Arabidopsis seedlings.

Previous studies using Arabidopsis seedlings demonstrated activation of defense responses upon exposure to the consensus flagellin-derived peptide flg22 (Felix et al. 1999). Seedlings exhibited induction of several classic defense response marker genes, including $P R-1$, within $24 \mathrm{~h}$ of treatment with f1g22 (Asai et al. 2002: Gomez-Gomez et al. 1999). Because wild-type $R$. solanacearum K60 synthesizes flagellin, we hypothesized that exposure of Arabidopsis seedlings to boiled extracts of K60 should result in increased expression of defense marker genes. Reverse transcription-polymerase chain reaction (RT-PCR) analysis was performed to test for induction of the classic defense marker PR-l. Seedlings treated with either f1g22 or with $R$. solanacearum K60 boiled extracts showed increased expression of PR-1 after $24 \mathrm{~h}$ (Fig. 1).

If flagellin is the major elicitor of PIZ gene induction in boiled extracts from K60, then boiled extracts from strains lacking flagellin should not induce PR-1 gene expression. To test this hypothesis, Arabidopsis seedlings were treated with boiled extracts from two mutant strains of $R$. solanacearum. Strain K701 carries an insertion in the $f l i C$ gene encoding flagellin and K702 carries an insertion in the flhDC locus, which encodes the master regulator of flagellin biosynthesis (Table 1) (Tans-Kersten et al. 2001; Tans-Kersten et al. 2004. Both of these strains are completely nonmotile in culture and in planta

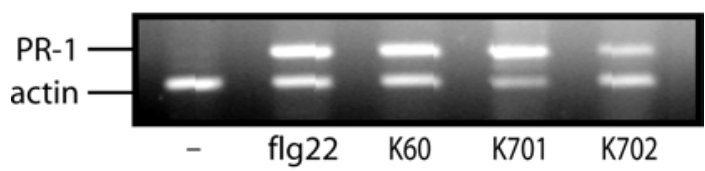

Fig. 1. Boiled extracts of Ralstonia solanacearum lacking flagellin induce defense gene expression. PR-1 RNA levels as detected by reverse transcription-polymerase chain reaction in whole Col-0 seedlings $24 \mathrm{~h}$ after treatment with water, $11 \mu \mathrm{g}$ flg22, or $45 \mu \mathrm{g}$ (total protein) of the indicated boiled bacterial extracts from K60 (wild-type), K701 (fliC), or K702 (flhDC). The top band was amplified using primers for $P R-1$, the bottom band was amplified using primers for actin (ACT2).

Table 1. Bacterial strains and plasmids

\begin{tabular}{|c|c|c|}
\hline Designation & Relevant characteristics ${ }^{\mathbf{a}}$ & Reference or source \\
\hline \multicolumn{3}{|c|}{ Escherichia coli } \\
\hline DH5 $\alpha$ & $\mathrm{F}^{-}$endA1 relA $\phi 80$ lacZ4M15 hsdR17 supE44 thi-1 recA1 gyrA96 & Hanahan 1983 \\
\hline \multicolumn{3}{|c|}{ Ralstonia solanacearum } \\
\hline K60 & Wild-type, race 1 , biovar 1 , tomato isolate & Kelman 1954 \\
\hline K71 & $\begin{array}{l}\text { Lacks the regulator pehSR, causing decreased polygalacturonase production and non-motile } \\
\text { phenotype K60 pehR::Tn3-uidA, Km }\end{array}$ & Allen et al. 1997 \\
\hline K701 & Disrupted gene for flagellinK60 fliC:: $\mathrm{Gm}^{\mathrm{r}}$ & Tans-Kersten et al. 2001 \\
\hline K702 & Disrupted master regulator of flagellin biosynthesis $\mathrm{K} 60 \mathrm{flhDC}:: \mathrm{Gm}^{\mathrm{r}}$ & $\begin{array}{l}\text { J. Tans-Kersten, } \\
\text { unpublished data }\end{array}$ \\
\hline K100 & Disrupted general secretion pathway $\mathrm{K} 60$ gsp $M:: \mathrm{Km}^{\mathrm{r}}$ & This study \\
\hline K200 & Disrupted $h r p B$ regulatory locus $\mathrm{K} 60 \mathrm{hrp} B:: \mathrm{Gm}^{\mathrm{r}}$ & This study \\
\hline AW-D & Wild-type race 1 biovar 1 tomato isolate AW-1 gspM::Tn5, $\mathrm{Km}^{\mathrm{r}}$ & Kang et al. 1994 \\
\hline K60-phcA & Disrupted LysR-type global regulator of virulence factors K60 phcA::strept & Allen et al. 1997 \\
\hline \multicolumn{3}{|c|}{ 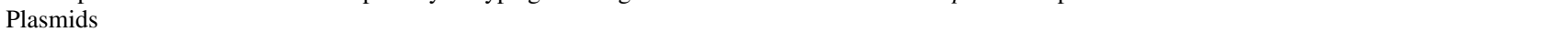 } \\
\hline pSTBlue-1 & A-T cloning vector, $\mathrm{Km}^{\mathrm{r}}$ & $\begin{array}{l}\text { Novagen, } \\
\text { Madison, WI, U.S.A. }\end{array}$ \\
\hline pUCGM & Contains gentamycin resistance cassette, $\mathrm{Gm}^{\mathrm{r}}$ & Novagen \\
\hline pHRPB 1 & 1,400-bp $h r p B$ fragment in EcoRV site of pSTBlue-1 & This study \\
\hline pHRPB2 & PhrpB1 with $850-\mathrm{bp} \mathrm{Gm}$ cassette in $B g l I I$ site of $h r p B$ & This study \\
\hline
\end{tabular}

${ }^{\mathrm{a}} \mathrm{Km}=$ kanamycin, $\mathrm{Gm}=$ gentamycin, and ${ }^{\mathrm{r}}=$ resistance. 
(Tans-Kersten et al. 2001; Tans-Kersten et al. 2004). Furthermore, boiled extracts prepared from strains K701 and K702 grown in culture lacked an approximately $30-\mathrm{kDa}$ band presumed to be flagellin, when analyzed by sodium dodecyl sulfate-polyacrylamide gel electrophoresis (SDS-PAGE) (data not shown). Arabidopsis seedlings treated with boiled extracts from strains K701 and K702 for 24 h showed increased PR-1 expression, similar to the response to boiled extracts from the wild-type strain K60 (Fig. 1). This suggests that flagellin is not necessary for the observed increase in PR-1 gene expression in Arabidopsis seedlings in response to these boiled extracts.

\section{Extracts of aflagellate $R$. solanacearum strains} elicit growth inhibition in Arabidopsis seedlings.

Previous results using Arabidopsis seedlings showed that prolonged exposure to the flagellin-derived peptide flg22 resulted in marked growth inhibition, correlating with the activation of defense responses (Gomez-Gomez et al. 1999). Growth inhibition is common in Arabidopsis constitutive disease-resistance mutants (Bowling et al. 1994; Clarke et al. 1998; Greenberg and

\section{A}

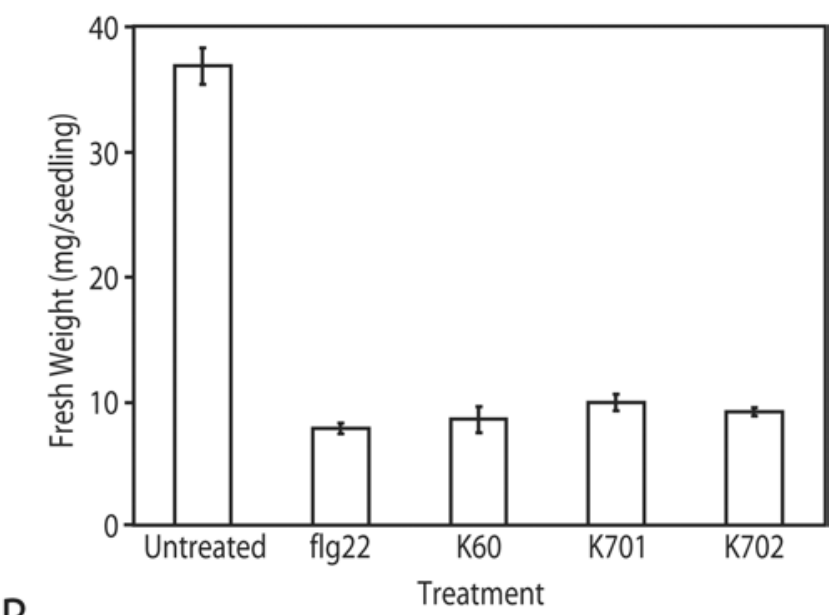

B

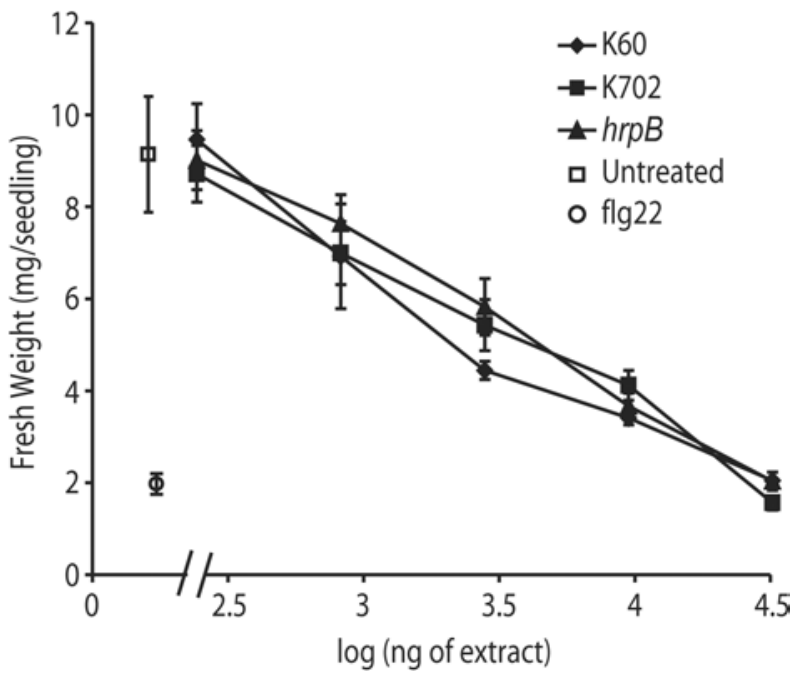

Fig. 2. Boiled extracts of Ralstonia solanacearum lacking flagellin elicit a growth inhibition in Arabidopsis seedlings. Average fresh weight measurements of nine Arabidopsis Col-0 seedlings. Seedlings A, 14 days after treatment with water, $11 \mu \mathrm{g}$ flg22, or $45 \mu \mathrm{g}$ (total protein) of the indicated boiled bacterial extracts and $\mathbf{B}, 7$ days after treatment with water, $11 \mu \mathrm{g}$ of flg22 (open symbols), or varying levels of the indicated extracts (closed symbols) ranging from $0.35 \mu \mathrm{g}$ to $35 \mu \mathrm{g}$ total protein. Bars represent standard error of the mean.
Ausubel 1993; Maleck et al. 2002; Petersen et al. 2000; Yu et al. 1998). Therefore, we used growth inhibition as a facile, indirect measure of defense gene activation (Fig. 1) (GomezGomez et al. 1999). Arabidopsis seedlings grown for 14 days in the presence of boiled extracts of $R$. solanacearum K60 were significantly reduced in weight compared with watertreated controls (Fig. 2A). The level of growth inhibition caused by $45 \mu \mathrm{g}$ (total protein) of boiled extract per well was comparable to the growth inhibition caused by $11 \mu \mathrm{g}(7.5 \mu \mathrm{M})$ f1g22 peptide, which was previously characterized as a strong growth inhibitor (Gomez-Gomez et al. 1999). This effect was detectable within 7 days of treatment (data not shown). This growth inhibitory response was not due to a general inhibition caused by the presence of bacterial proteins at this concentration, as similarly prepared extracts from another phytopathogenic bacterium, Xanthomonas campestris pv. campestris, applied at this same concentration did not inhibit growth (C. Pfund and A. F. Bent, unpublished data).

Arabidopsis seedlings treated with boiled extracts from aflagellate $R$. solanacearum K701 and K702 demonstrated significant growth inhibition that was indistinguishable from the response to extracts from the wild-type parent strain K60 (Fig. 2A). Moreover, the dose-response curve was the same for seedlings treated with boiled extracts from all three strains of $R$. solanacearum, suggesting that growth inhibition by these strains is due to one or more similar elicitors (Fig. 2B). Together, the above results (Figs. 1 and 2) suggest that flagellin is not necessary for defense gene activation or the correlative growth inhibition of Arabidopsis seedlings caused by boiled extracts of $R$. solanacearum.

\section{Elicitation does not occur through the Arabidopsis FLS2 receptor.}

We tested the ability of the $R$. solanacearum extracts to elicit a growth response in Arabidopsis seedlings lacking functional FLS2. FLS2 is a transmembrane LRR receptor kinase that has been shown to bind $\mathrm{f} 1 \mathrm{~g} 22$ and activate defense gene transcription in Arabidopsis; mutations in FLS2 render Arabidopsis seedlings unresponsive to the f1g22 peptide (Gomez-Gomez and Boller 2000). If flagellin is the primary elicitor in boiled extracts of K60 and if FLS2 is the primary flagellin receptor, then plants lacking FLS2 would be expected to show less of a response to boiled extracts. In addition, if the $R$. solanacearum nonmotile mutants K701 and K702 retain some elicitation capacity because of an undetected ability to synthesize low levels of flagellin (K702) or an N-terminal fragment of flagellin

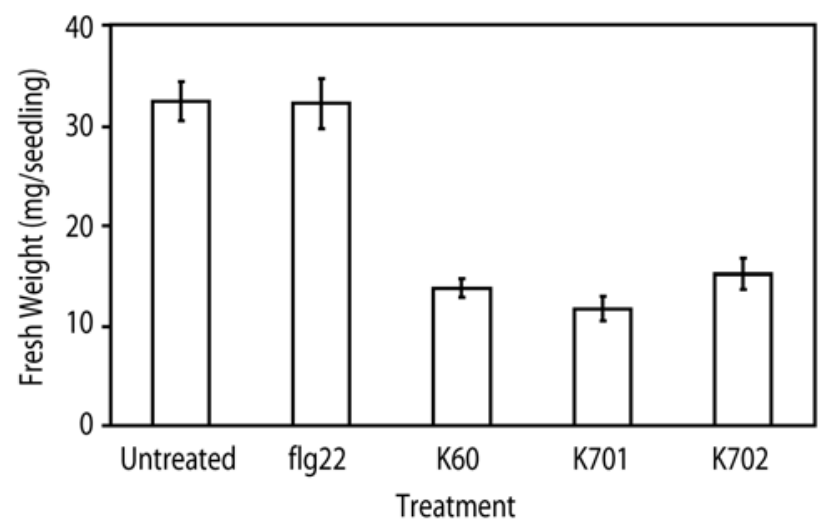

Fig. 3. Elicitation of growth inhibition does not require FLS2 receptor Average relative fresh weight measurements of nine Arabidopsis fls2-101 seedlings treated with water, $11 \mu \mathrm{g}$ flg 22 , or $45 \mu \mathrm{g}$ of the indicated boiled bacterial extract. Fresh weights of seedlings were determined 14 days after treatment. Bars represent standard error of the mean. 
(K701), one could hypothesize that disruption of the putative flagellin receptor would detectably reduce the responsiveness of seedlings to boiled extracts from these strains.

We identified an Arabidopsis line homozygous for a T-DNA insertion in FLS2 (fls2-101). As expected, flsr2-101 seedlings were unresponsive to $\mathrm{f1g} 22$ (Fig. 3). However, fls2-101 seedlings did demonstrate a marked response when treated with boiled extracts from K60, K701, and K702 (Fig. 3). In replicated experiments, there were no reproducible differences between the weights of Col-0 and fls2-101 seedlings in response to a given extract (Figs. 2A and 3). These data suggest that the primary elicitor in $R$. solanacearum is not flagellin and demonstrate that this elicitation does not require the flagellin receptor FLS2.

Tobacco responds to nonmotile bacterial cells and extracts.

We also wanted to determine if cell-associated proteins from wild-type and aflagellate $R$. solanacearum strains could elicit a response in tobacco (Nicotiana tabacum), a natural host of strain K60. We infused the apoplastic space of tobacco leaves with live bacteria or semipurified cell-associated proteins from cells grown in minimal medium. When live cultures of $\mathrm{K} 60$, $\mathrm{K} 701$, and K702 were infused into tobacco leaves at $1 \times 10^{7}$ $\mathrm{CFU} / \mathrm{ml}$, the infused leaf tissue became chlorotic after $18 \mathrm{~h}$ and was completely collapsed and necrotic $40 \mathrm{~h}$ after infusion, with no difference between strains (data not shown). There was a minor response to bacterial protein extracts. At 500 $\mu \mathrm{g} / \mathrm{ml}$ boiled extracts from K701, K702, and wild-type K60 all caused slight chlorosis (leaf yellowing) after $24 \mathrm{~h}$ and showed marked chlorosis after $76 \mathrm{~h}$, with no distinguishable difference between treatments. There was no detectable plant response from extracts applied to leaves at $50 \mu \mathrm{g} / \mathrm{ml}$. possibly because the relevant protein concentrations were too low. These results suggest that cell-associated proteins from live $R$. solanacearum cells or crude bacterial preparations can elicit a response in tobacco leaves, even in the absence of the putative flagellin elicitor.

\section{The f1g22 region \\ of K60 does not elicit a response in Arabidopsis.}

Our results suggest that flagellin is not the major elicitor in $R$. solanacearum. However, we wanted to further investigate the eliciting capacity of $R$. solanacearum flagellin by focusing on its flg22 region. This region is more conserved across diverse bacterial species than are most other regions of bacterial flagellin. Peptides based on the f1g22 sequence from Pseudomonas aeruginosa, Escherichia coli, and other species have strong eliciting activity (Felix et al. 1999). We compared the amino acid sequence of the consensus fig22 oligopeptide to that of the same region in the flagellin of $R$. solanacearum K60 (f1g22-K60). The flg22-K60 sequence differs from the previously studied flg22 sequence at several positions, some of which have previously been shown to be critical for full elicitation in tomato cells (Fig. 4A). In particular, the Gly to Ala change at position 18 has previously been shown to reduce the alkalinization-inducing activity of $\mathrm{f} 1 \mathrm{~g} 22$ in tomato cells by 96\% (Felix et al. 1999).

To test the elicitation ability of the f1g22-K60, Arabidopsis seedlings were treated with $10 \mu \mathrm{M}$ of either flg22 or flg22K60 for seven days. Seedlings heated with the f1g22-K60 did not show a significant growth inhibition compared with untreated controls, while the original flg22 peptide did (Fig. 4B). This absence of flg22-K60 perception by the plant may be coincidental or may have arisen due to selective pressures. For example, the flg22 region of $R$. solanacearum flagellin may have evolved to escape detection by the plant FLS2-flagellin detection system.
The boil-resistant elicitor from $\boldsymbol{R}$. solanacearum is protein.

We pursued initial structural characterization of the boilresistant, nonflagellin elicitor. Extracts of $R$. solanacearum K60 treated with proteinase $\mathrm{K}$ no longer elicited significant growth inhibition in Arabidopsis seedlings (Fig. 5A). Treatment of K60 extracts with a generic protease gave similar results (data not shown). These data suggest that the elicitor is a protein. Gel filtration over Sephadex G-50 separated elicitation activity into both higher and lower molecular weight (MW) fractions (Fig. 5D and E). Elicitation from the later fractions was assignable to low-MW proteins, as opposed to the tail of a broad peak of higher-MW proteins because, in separate experiments, elicitation activity was present in extracts that had been centrifuged through filters with a stated molecular mass cut-off range centered at $5 \mathrm{kDa}$ (Fig. 5C).

The possibility that the elicitor is a small peptide was also investigated, as some well-known microbially derived plant defense elicitors and toxins are small peptides (Hahn 1996; Scheel and Parker 1990). K60 extracts reproducibly showed similar elicitation activities before and after extensive dialysis, using dialysis membrane with a stated molecular mass cut-off range centered at $7 \mathrm{kDa}$ (Fig. 5B). Extracts dialyzed using membranes with a molecular mass cut-off of $10 \mathrm{kDa}$ in four independent experiments showed either no detectable reduction in elicitation or some reduction of elicitation (data not

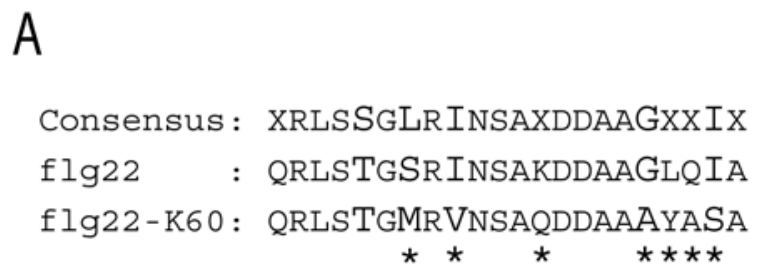

B

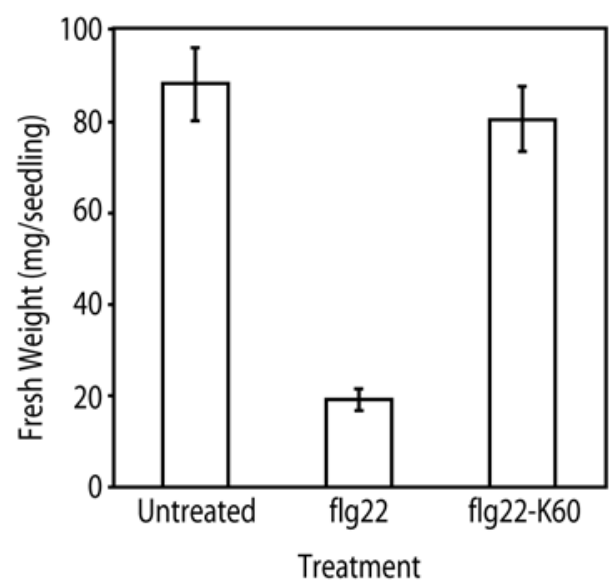

Fig. 4. A peptide derived from the flg22-region of K60 flagellin does not elicit a growth response in Arabidopsis seedlings. A, Amino acid alignment of the N-terminal flg22 region of flagellin derived from a consensus sequence (Felix et al. 1999), the standard flg22 peptide used in many studies, including the present study (Felix et al. 1999), or the sequence of the flg22-K60 peptide designed based on the corresponding region of flagellin from Ralstonia solanacearum K60. Amino acid differences between the original flg22 and the $R$. solanacearum-derived peptide are noted with an asterisk (*). Amino acids in the $R$. solanacearum-derived peptide that differ from the consensus are shown in larger font. B, Average fresh weight measurements of nine Arabidopsis (Col-0) seedlings treated with $10 \mu \mathrm{M}$ flg22 or $10 \mu \mathrm{M}$ flg22-K60. Weights of seedlings were taken 7 days after treatment. Bars represent standard error of the mean. 
shown). Collectively, the above experiments suggest that the eliciting activity is not caused primarily by a small peptide but is, instead, caused by one or more proteins with a molecular mass of roughly 5 to $10 \mathrm{kDa}$.

Additional eliciting activity was evident in larger MW fractions collected after gel filtration (Fig. 5D and E). We were unable to determine if the larger elicitors were single large proteins or aggregates of the smaller elicitor. SDS treatment to dissociate possible aggregates followed by SDS removal eliminated elicitation activity (Fig. 5C). This may have been due to denaturation of one or more boil-resistant eliciting proteins by SDS or due to loss of small elicitor proteins during the post-SDS dialysis, which was required to remove SDS so that extracts could be assayed on Arabidopsis seedlings. Note that fractions from gel filtration were re-boiled immediately prior to application to seedlings for elicitation experiments, possibly redenaturing or redissociating proteins, or both, that had previously been boiled during the initial preparation of all bacterial extracts.

\section{Elicitor production is not controlled by known virulence regulators.}

To further investigate the nature of this elicitor, we examined the elicitation activity of boiled extracts derived from $R$. solanacearum strains carrying mutations in secretion pathways, regulators of known virulence factors, or both (Denny 2000). Strain K60-phcA no longer expresses PhcA, the LysRtype global regulator of virulence factors. This strain is motile but has severely reduced exopolysaccharide and endoglucanase production, has increased extracellular polygalacturonase production, and is essentially nonvirulent (Brumbley et al. 1993). Strain K71 lacks the two-component regulator product of pehsR, causing decreased polygalacturonase production and a nonmotile phenotype (Allen et al. 1997); K71 exhibits sig-
A

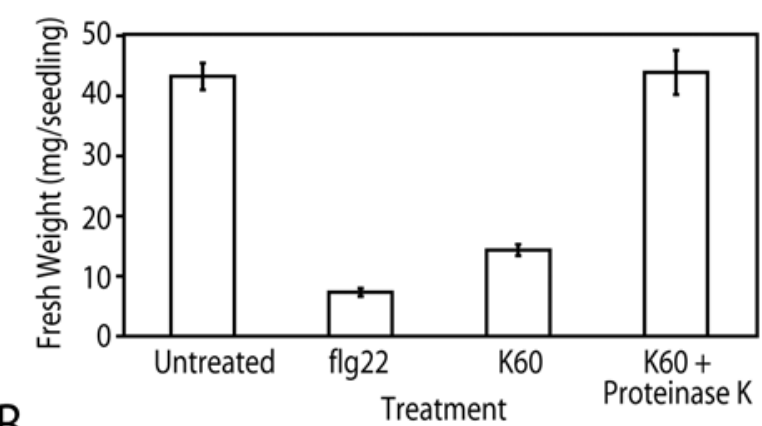

B
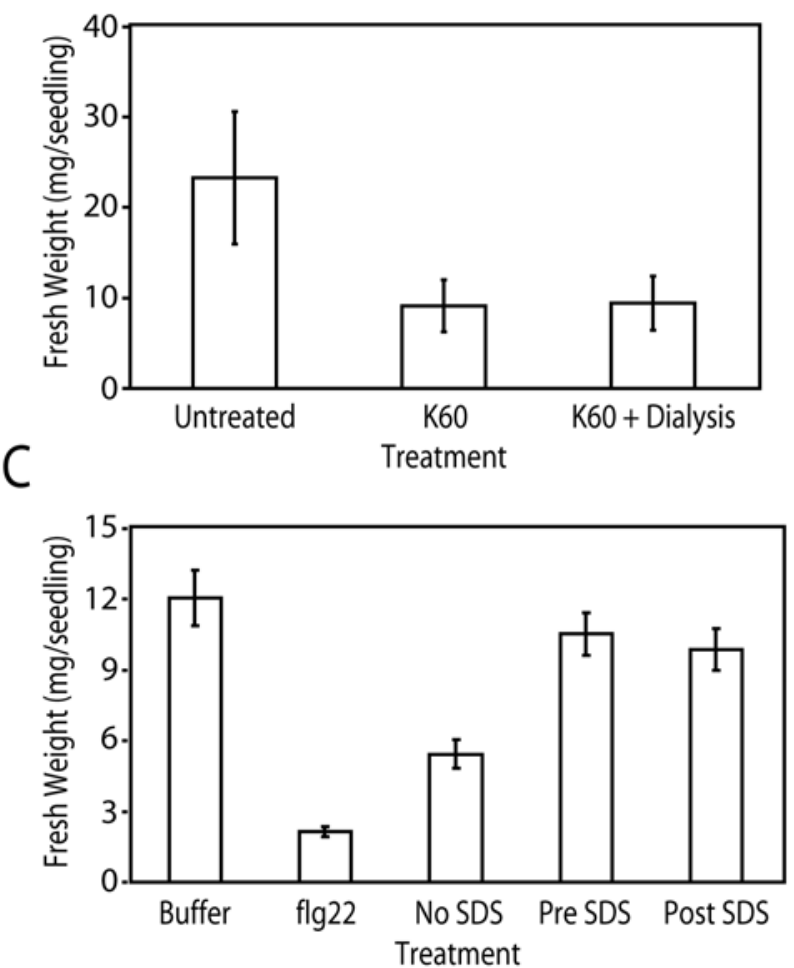

D

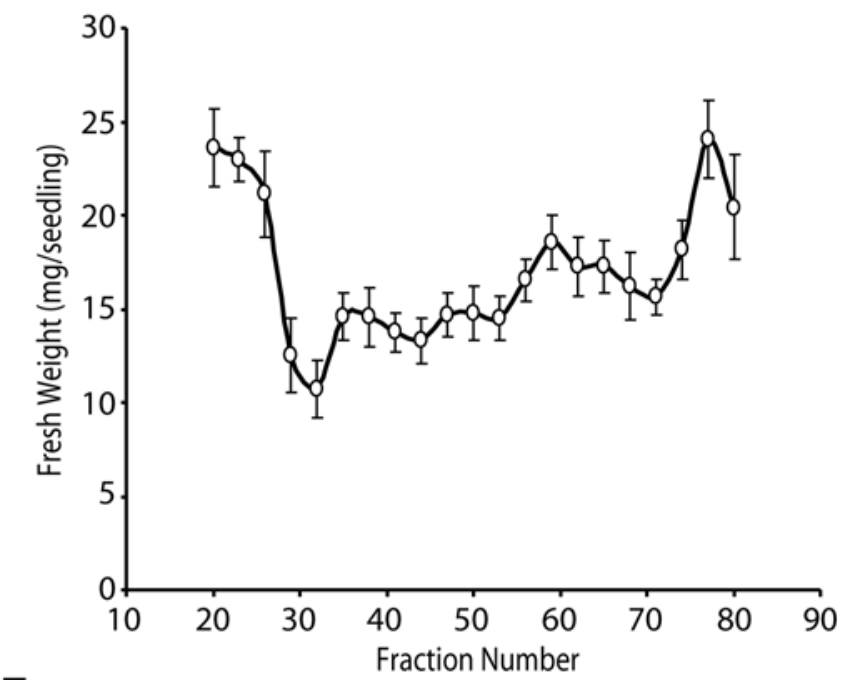

E

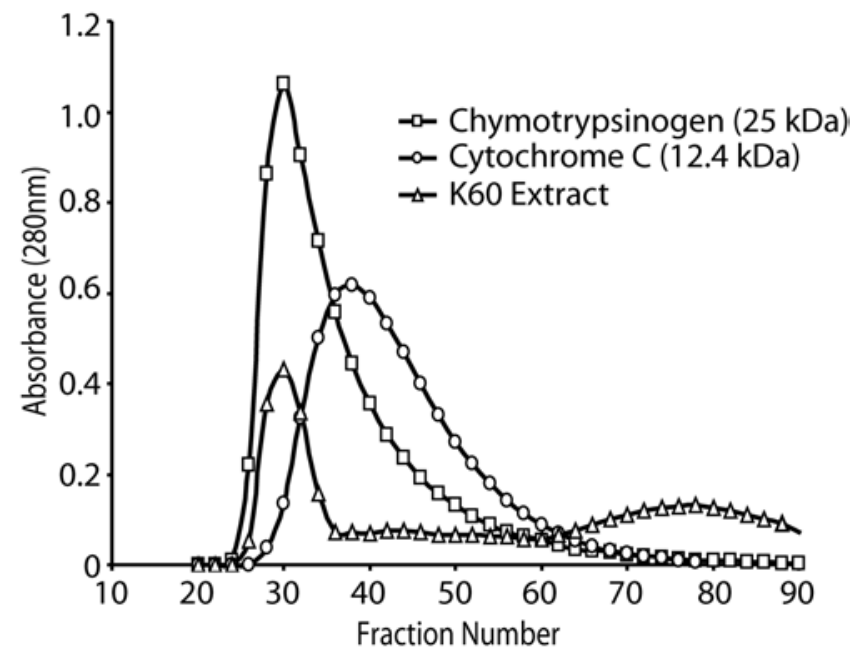

Fig. 5. Seedling growth inhibition is caused by one or more proteins purifying between 5 to $10 \mathrm{kDa}$ as well as by proteins that purify at a larger apparent size. Average fresh weight measurements are for nine Arabidopsis (Col-0) seedlings weighed after 14 days of treatment. Bars represent standard error of the mean. A, Seedlings treated with water, $10 \mu \mathrm{M}$ flg22, or $45 \mu \mathrm{g}$ of boiled bacterial extracts from K60 either with or without proteinase K treatment. B, Seedlings treated with approximately $30 \mu \mathrm{g} \mathrm{K60} \mathrm{extract} \mathrm{that} \mathrm{was} \mathrm{or} \mathrm{was} \mathrm{not} \mathrm{dialyzed} \mathrm{in} \mathrm{7-kDa} \mathrm{molecular} \mathrm{mass} \mathrm{cut-off} \mathrm{dialysis} \mathrm{tubing.} \mathrm{C,} \mathrm{Seedlings} \mathrm{treated}$ with water, $10 \mu \mathrm{M}$ flg22, K60 extract passaged through a 5-kDa molecular mass cut-off ultrafiltration unit, or K60 extract treated with $0.4 \%$ sodium dodecyl sulfate (SDS) before (pre) or after (post) passage through a 5-kDa molecular mass cut-off ultrafiltration unit and then dialyzed in 3.5-kDa molecular mass cut-off dialysis tubing to remove SDS. D, Seedlings treated with K60 extract fractions from a Sephadex G-50 gel filtration column (top panel). E, Elution profile for the K60 extract fractions used in panel D and for two protein size standards previously run on the same Sephadex G-50 column. 
nificantly reduced virulence. The 'out' mutant K100 has a Tn5 insertion in the gspM locus that disrupts the general secretion pathway and leads to dramatically reduced virulence (Kang et al. 1994). K200 has a gentamycin resistance cassette insertion in the $h r p B$ regulatory locus. HrpB is a positive regulator of the $R$. solanacearum type III secretion system, which transfers effector proteins into host plant cells. HrpB is also required for expression of a suite of putative effector proteins. hrpB mutants can no longer cause disease on host plants or induce a hypersensitive response in nonhost plants (Genin 1992).

Boiled extracts from these strains were tested for their ability to elicit defense-associated responses in Arabidopsis seedlings. Extracts from K100 (gspM), K200 (hrpB), K71 (pehR), and K60-phcA all elicited a seedling growth-inhibition response indistinguishable from that elicited by the wild-type K60 extract (Figs. 1B and 6A and B). Thus, mutations disrupting these known regulators and secretory pathways do not affect expression of one or more elicitors detected in $R$. solanacearum boiled extracts.

\section{The $R$. solanacearum elicitor is not an avirulence factor.}

It can be hypothesized that the elicitor in $R$. solanacearum K60 boiled extracts is an avirulence gene product. Pathogen avirulence $(a v r)$ genes are defined by their functional interaction with the plant host through the action of corresponding plant resistance $(R)$ genes, which typically activate rapid and robust defense responses that restrict pathogen invasion

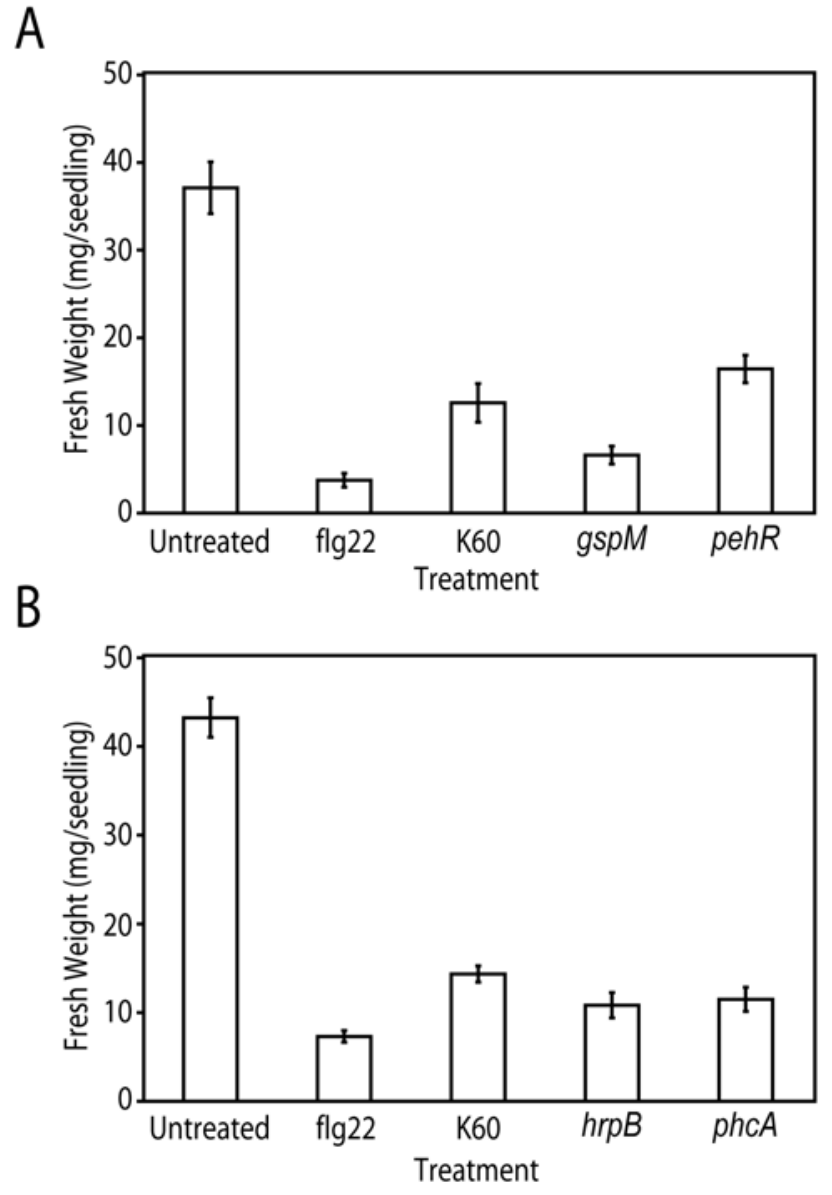

Fig. 6. Extracts from diverse Ralstonia solanacearum virulence mutants elicit a response in Arabidopsis. Average relative fresh weight measurements of nine Arabidopsis (Col-0) seedlings treated with water, $11 \mu \mathrm{g}$ flg22, or $45 \mu \mathrm{g}$ of the indicated boiled bacterial extract. Fresh weights of seedlings were determined 14 days after treatment. Panels A and B depict independent experiments. Bars represent standard error of the mean.
(Dangl and Jones 2001). If K60 contains an avr gene product that is recognized by Arabidopsis Col-0, then K60 should be largely unable to cause disease on Arabidopsis Col-0 and might elicit a hypersensitive response. We tested the virulence of K60 on Arabidopsis plants using a soil soak assay following root wounding, which has previously been used to demonstrate virulence of another $R$. solanacearum strain, GMI1000 (Deslandes et al. 2002). R. solanacearum K60 was virulent on Arabidopsis Col-0 (Fig. 7), the same Arabidopsis genotype used in our earlier experiments, indicating that the defenseeliciting activity present in boiled extracts of K60 is not causing an $a v r$ phenotype, in that it does not correlate with effective whole plant disease resistance in the same plant genotype.

We also tested the ability of wild-type strain K60 and nonmotile strain K701 to cause disease in wild-type Col-0 Arabidopsis and in Col-0 plants lacking the FLS2 receptor. If flagellin or another elicitor is recognized by this receptor, it should activate defense induction and cause a corresponding decrease in disease. However, K60 caused statistically indistinguishable levels of disease on wild-type Col-0 and fls2-101 (Fig. 7). The loss of flagellin also had little or no impact on pathogen virulence (Fig. 7). These data indicate that the presence of FLS2 in the plant or flagellin in the pathogen does not significantly affect the wholeplant response to live $R$. solanacearum bacteria in our assays.

Separate front the main focus of this study, the data presented in Figure 7 also support the previous finding that flagella-mediated motility is not necessary for virulence if bacteria are delivered to wounded plant surfaces at a sufficiently high concentration (Tans-Kristen et al. 2001).

\section{DISCUSSION}

A critical component of immunity is the ability of an organism to recognize nonself invaders. Conserved pathogen-associated molecular patterns displayed on the surface of microbes

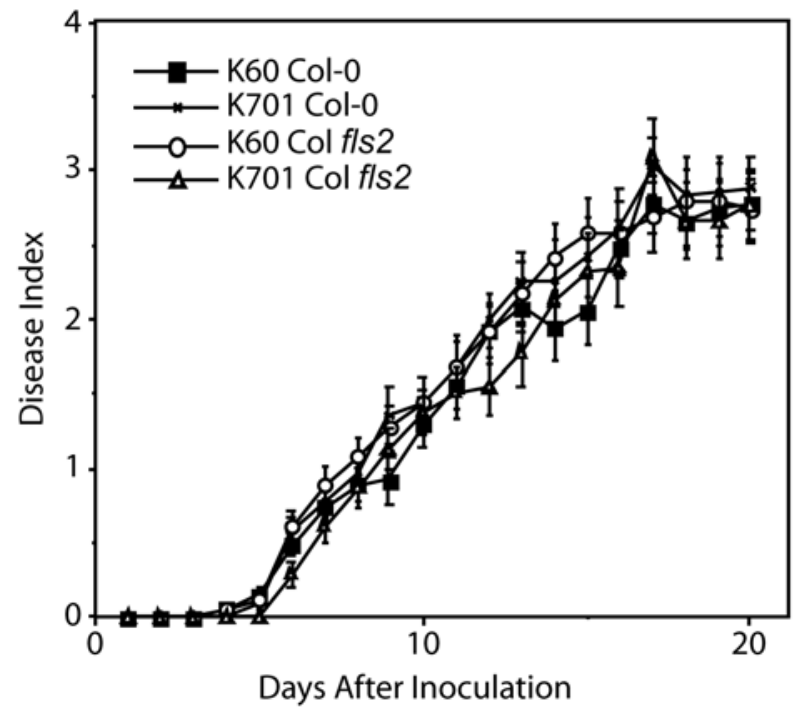

Fig. 7. Wild-type and aflagellate Ralstonia solanacearum strains cause similar disease levels on Arabidopsis with and without the FLS2 receptor. Soil-soak virulence assay on Arabidopsis Columbia (Col-0) and Arabidopsis $\mathrm{Col} f l s 2$ ( $f l s 2-101)$. In three separate experiments that each included all treatments, four-week-old Arabidopsis plants were inoculated by soil drench with $10 \mathrm{ml}$ of a bacterial suspension immediately after roots had been injured by a serrated knife passing through the soil. Each datapoint is the mean \pm standard error of the mean for 45 to 46 plants total for each treatment, which incorporates data from all three replicate experiments. Solid squares represent K60 (wild-type) on Col-0; crosses represent K701(fliC) on Col-0; open circles represent K60 (wild-type) on Col-0 fls2; and open triangles represent K701(fliC) on Col-0 fls2. 
are thought to serve as recognition cues that the host uses to trigger defenses (Darvill et al. 1984; Ebel and Scheel 1997; Medzhitov et al. 2002; Nurnberger and Brunner 2002). In animal innate immune systems, toll-like transmembrane receptors are involved in recognition of pathogen-associated molecular patterns, including bacterial flagellins and in the subsequent activation of immune responses (Aderem 2001; Hayashi et al. 2001; Imler and Hoffmann 2001; Khush and Lemaitre 2000; Smith and Ozinsky 2002). Recent studies have focused on the recognition of bacterial flagellin by several plants (Donnelly and Steiner 2002; Felix et al. 1999; Gomez-Gomez and Boller 2002; Taguchi et al. 2003; Tananka et al. 2003). Recognition of flagellin by Arabidopsis has been attributed to FLS2, a leucine-rich receptor-like kinase that activates plant defense at least in part via a MAP kinase pathway (Asai et al. 2002; Gomez-Gomez and Boller 2000, 2002). However, the impact of flagellin expression on bacterial virulence and the efficacy of the plant defenses activated following flagellin recognition remain unclear.

Phytopathogenic $R$. solanacearum bacteria require motility for full virulence (Tans-Kersten et al. 2001 ). Previous work using cultured tomato cells implicated flagellin as the primary elicitor of plant defense responses in boiled extracts from many phytopathogenic bacteria (Felix et al. 1999). Furthermore, exposure of Arabidopsis seedlings to a peptide derived from a conserved $\mathrm{N}$-terminal flagellin domain (f1g22) leads to induction of classic defense marker genes and a correlative seedling growth inhibition (Gomez-Gomez et al. 1999). We considered that flagellin of $R$. solanacearum may serve as a pathogen-associated molecular pattern recognizable by host plants and capable of activating plant immune responses. We found that boiled extracts of $R$. solanacearum K60 did inhibit seedling growth and induce defense gene expression (Figs. 1 and 2). However, flagellin from $R$. solanacearum was not the primary elicitor in boiled extracts (Figs. 1 and 2), and the virulence of $R$. solanacearum on Arabidopsis plants did not differ between flagellate and aflagellate strains (Fig. 7). Moreover. the absence of the FLS2 receptor in Arabidopsis did not significantly affect the ability of Arabidopsis to respond to this elicitor (Fig. 3) or to defend itself against $R$. solanacearum infection (Fig. 7). As an aside. our data also demonstrated that $R$. solanacearum does not require motility for virulence in Arabidopsis following a soil-soak method of inoculation that uses wounded plants and a high titer of bacteria (Fig. 7).

The above findings were somewhat unexpected, as earlier work had implicated flagellin as the major elicitor of defense responses in boiled extracts from many phytopathogenic and nonpathogenic bacteria (Felix et al. 1999). However, those experiments were done in tomato and not Arabidopsis, and were done in suspension culture cells rather than whole plants. It is possible that Arabidopsis seedlings possess a functional receptor for one or more additional elicitors that are lacking in tomato suspension culture cells. However, in a very recent study of boiled extracts from more than 20 different bacteria, all of which elicited defense-associated responses, elicitation activity in some cases was attributed to a cold-shock protein rather than flagellin (Felix and Boller 2003). Note also that not every boiled bacterial extract can elicit plant responses. We have observed that extracts from some strains of the phytopathogenic bacterium Xanthomonas campestris pv. campestris do not elicit growth inhibition in Arabidopsis seedlings (C. Pfund, unpublished data).

A preliminary analysis of the elicitor or elicitors present in $R$. solanacearum extracts indicated that it is proteinaceous in nature and resistant to boiling. At least one primary fraction of elicitor has an apparent molecular mass of 5 to $10 \mathrm{kDa}$; dialysis experiments suggested that elicitation is not substantially due to a small peptide, but gel filtration work did indicate that elicitation is also caused by larger proteins, aggregates, or both (Fig. 5). Previous work on elicitors from phytopathogenic bacteria suggested that this elicitor might be a harpin, which are small, heat-resistant proteins that are secreted via the type III secretion apparatus and can activate plant defenses (He et al. 1993; Wei et al. 1992). Our results indicated that this is not the case, as extracts from a $R$. solanacearum hrpB mutant retain the ability to elicit plant response (Figs. $2 \mathrm{~B}$ and $6 \mathrm{~B}$ ). $\mathrm{HrpB}$ is a positive regulator of expression, not only of the type III secretion apparatus, but also of many putative effector proteins, such as the PopA harpin (Denny 2000; Genin 1992). Extracts from $R$. solanacearum strains harboring mutations in phcA, pehR, or gspM also retained wild-type ability to elicit responses in Arabidopsis seedlings, indicating that expression of elicitor also does not require the PhcA or PehR regulons or the general secretory pathway. Other potential elicitors, such as lipopolysaccharides, pectic fragments, and glycoproteins (Nuhse et al. 2000) would likely be sensitive to boiling or insensitive to proteinase $\mathrm{K}$ treatment, and therefore, do not fit our profile.

Use of seedling growth as an assay that correlates with defense activation has been extensively documented (Figs. 1 and 2) (Gomez-Gomez and Boller 2000; Gomez-Gomez et al. 1999; C. Pfund and A. F. Bent, unpublished data), and many laboratories have observed that constitutive activation of defenses causes Arabidopsis plants to be dwarfed (Bowling et al. 1994; Clarke et al. 1998; Greenberg and Ausubel 1993; Maleck et al. 2002; Petersen et al. 2000; Yu et al. 1998). The f1g22 peptide causes both PR gene expression and seedling growth inhibition, and these two traits correlated in all cases that we tested with $R$. solanacearum extracts. However, if the eliciting activity in $R$. solanacearum boiled extracts is, in fact, attributable to more than one different protein, the possibility exists that elicitation of defense and of seedling growth inhibition may be separable.

Recent work has revealed the presence of another major boil-resistant elicitor of plant defense responses found in extracts of Micrococcus lysodeikticus (Felix and Boller 2003). This elicitor is a member of the cold-shock protein (CSP) family. While the $R$. solanacearum genome does encode proteins annotated as CSPs, two pieces of data suggest that our elicitor may not be a CSP. First, a peptide derived from a conserved domain found in CSPs did not elicit a response in .Arabidopsis culture cells (Felix and Boiler 2003). Secondly, treatment of extracts of M. lysodeikticus, using molecular mass cut-off 10 $\mathrm{kDa}$, completely eliminated the CSP elicitor (Felix and Boller 2003), whereas we retained elicitation activity following dialysis in membrane with a stated cut-off of $10 \mathrm{kDa}$. Further biochemical analysis of extracts from $R$. solanacearum should help identify one or more elicitors that are capable of causing seedling growth inhibition and the corresponding induction of defense gene in Arabidopsis and, presumably, other plants.

In tobacco, a natural host of $R$. solanacearum, live cells of the fliC mutant K701 elicited a rapid tissue chlorosis and necrosis that was indistinguishable from the response induced by wild-type strain K60. Furthermore, crude boiled extracts derived from nonmotile strains $\mathrm{K} 701$ (fliC) and K702 (flhDC) caused mild chlorosis in tobacco, just like extracts from the wild-type strain K60. This preliminary result extends our findings beyond Arabidopsis and suggests that $R$. solanacearum produces nonflagellin elicitors that are detected by a natural host species.

While our data indicate that flagellin is not the major elicitor of plant responses in boiled extracts of $R$. solanacearum, our data also indicated that the $R$. solanacearum flagellin may not be recognized by the Arabidopsis flagellin-recognition 
system (Fig. 4). Previous data indicated that the conserved f1g22 region of bacterial flagellin is sufficient to elicit response in Arabidopsis (Gomez-Gomez et al. 1999). We found that a peptide derived from the $R$. solanacearum version of this same region did not elicit a response in Arabidopsis (Fig. 4B). The sequence of this $R$. solanacearum $\mathrm{f} 1 \mathrm{~g} 22$ region contains at least one significant change from a consensus sequence derived from the flagellin of many bacteria (Fig. 4A) (Felix et al. 1999). Felix and associates (1999) demonstrated that peptides derived from the flagellins of Agrobacterium and Rhizobium spp. had no elicitation activity and suggested that some plant-associated bacteria may have altered flagellins that elude flagellin-dependent detection. $R$. solanacearum flagellin may also fall into this group. Interestingly. FLS2 was found to he highly expressed in the plant vasculature (Gomez-Gomez and Boller 2002). As R. solanacearum is a vascular pathogen, these data are consistent with a strong selection pressure for vascular pathogens that can elude detection via FLS2.

It is unclear at this point whether plants that do detect flagellin recognize assembled flagella shed from the bacterium, free flagella, or fragments of degraded flagellin. Alternative epitopes of' flagellin may be displayed by shed flagella compared with intact flagellin. The $\mathrm{f} 1 \mathrm{~g} 22$ region of flagellin is normally buried in the assembled polymer's tertiary structure (MacNab 1996), suggesting that the flagellin molecule recognized by FLS 2 may be unfolded or partially degraded. Recent evidence suggests that the $\mathrm{N}$-terminal $\mathrm{f} 1 \mathrm{~g} 22$ region may not be the sole determinant of flagellin recognition by plants (Che et al. 2000; Taguchi et al. 2003; Tananka et al. 2003). Our results with aflagellate $R$. solanacearum strains demonstrated that any elicitation caused by other flagellin domains was insufficient to be detectable over and above the other elicitors present in the strains or extracts used.

Our investigation was initially focused on flagellin elicitation, but it raised general questions as to whether elicitors identified in pathogen extracts offer a productive route to identification of biologically relevant elicitors. Despite the presence of an extractable defense elicitor, $R$. solanacearum K60 is highly virulent on Arabidopsis. It is possible that the defenses activated in response to this elicitor have only minor effects on pathogen virulence that were undetectable in our assays. Alternatively, $R$. solanacearum may be effective in overcoming or suppressing the modest host resistance activated by this elicitor. Other host or nonhost species may be more responsive to the presence of such elicitors. However. the possibility must also be considered that these elicitors are not biologically relevant.

We demonstrate that flagellin is not the major elicitor of Arabidopsis defense gene induction in boiled extracts of $R$. solanacearum, although these $R$. solanacearum extracts do contain defense-eliciting activity. There may be many molecules capable of eliciting plant defenses (Hahn 1996; Scheel and Parker 1990). However, the relevance of such putative pathogen-associated molecular patterns in plant disease is unclear. Identification of these elicitors, isolation of mutant strains that are disrupted in elicitor production, and subsequent analysis of the virulence of these live pathogens will help us to better understand the role of these elicitors in plant disease and disease resistance.

\section{MATERIALS AND METHODS}

\section{Bacterial strains and culture conditions.}

Bacterial strains and plasmids used in this study are listed in Table 1. R. solanacearum strains were grown at room temperature in CPG broth or CPG agar amended with $0.05 \%$ triphenyltetrazolium chloride (Hendrick and Sequeira 1984). Boucher's minimal media broth (BMM) (Boucher et al. 1985) with $0.2 \%$ glucose was used when minimal media was required. Antibiotics (Sigma Chemical, St. Louis) were added as necessary in the following concentrations (mg per liter): tetracycline, 15; gentamycin, 25; kanamycin, 25; and streptomycin, 30.

\section{Cloning and mutagenesis of $g s p M$ and $h r p B$ genes.}

Isolation of plasmid and chromosomal DNA, restriction mapping, subcloning, and PCR were performed using standard methods (Ausubel et al. 1995). Escherichia coli was transformed by electroporation as previously described (Ausubel et al. $1995)$. $R$. solanacearum was transformed either by electroporation (Allen et al. 1991) or by natural transformation (T. Denny, personal communication).

To create the $g s p M$ (out) mutant K100, AW-D (gspM::Tn5; Table 1) genomic DNA was naturally transformed into $R$. solanacearum K60. Briefly, recipient strain K60 was grown overnight in CPG broth to an optical density at $600 \mathrm{~nm}$ $\left(\mathrm{OD}_{600}\right)$ of 0.5 . Cells were centrifuged at $7,000 \times g$ for $3 \mathrm{~min}$ and the supernatant was discarded. Cells were mixed with 3 $\mu \mathrm{g}$ of genomic DNA, were spotted on a CPG plate, and were incubated overnight at $28^{\circ} \mathrm{C}$. Cells were subsequently scraped and re-plated on selective media. Kanamycin-resistant transformants were screened for lack of extracellular cellulase and polygalacturonase activities by the cellulase plate assay (Chatterjee et al. 1995) and thin-layer chromotography, respectively (Huang and Allen 1997).

The hrpB locus was cloned, using PCR primers designed from the $R$. solanacearum GMI1000 genomic sequence available on INRA's Ralstonia solanacearum webpage. The primers were 5' ATGCTGGGAAACATCTAC 3' and 5' GCTTCG TTGAACTGCTTG $3^{\prime}$. A 1,400-bp product containing $h r p B$ was cloned into pSTBlue-1 to create pHRPB1, and the correct sequence was confirmed by sequencing. A single $B g l I I$ site within $h r p B$ was used to insert an 850-bp gentamycin resistance cassette (pHRPB2). This mutagenesis construct was marker-exchanged into the $R$. solanacearum K60 genome by homologous recombination. Gentamycin-resistant transformants were screened by PCR for an 850-bp cassette insertion in the $h r p B$ gene. Mutants were also screened for inability to cause a rapid necrosis in tobacco leaves (Boucher et al. 1985) and for dramatically reduced virulence by petiole inoculation in tomato plants (discussed below) (Tans-Kersten et al. 2001). The $R$. solanacearum K60 hrpB mutant strain was named K200 (Table 1).

\section{Arabidopsis lines and seedling growth conditions.}

Arabidopsis thaliana ecotype Col-0 plants were used as wild-type plants. The fls2-101 mutant allele was generated at the Salk Institute Arabidopsis Knock-Out Facility (JP71.4 G09; La Jolla, CA, U.S.A.) (Alonso et al. 2003). The homozygous presence of an insertion in the $h L S 2$ locus was subsequently confirmed by Southern blot analysis, PCR, and insensitivity to the f1g22 peptide by growth-inhibition analysis. For seedling growth assays, all seeds were sterilized by standard bleach sterilization (Clough and Bent 1998), were stratified for 2 days, were germinated on $1 / 2$ Murashige-Skoog (MS) plates containing $0.8 \%$ plant tissue culture agar (Sigma) containing $2 \%$ sucrose and vitamins ( $1 \mathrm{ml} / \mathrm{liter})$ (Sigma), and were grown for 5 days at room temperature $\left(22^{\circ} \mathrm{C}\right)$ under $18 \mathrm{~h}$ of light. Seedlings were then transferred to 24-well culture dishes containing $400 \mu \mathrm{l} \frac{1}{2} \mathrm{MS}$ media. Total protein $(45 \mu \mathrm{g}$ of each boiled extract unless otherwise indicated) or $11 \mu \mathrm{g}$ (7.5 to 9.0 $\mu \mathrm{M}) \mathrm{f} 1 \mathrm{~g} 22$ peptides were added to each well $(1.5-\mathrm{cm}$ diameter), and the seedlings were incubated for the indicated time at $22^{\circ} \mathrm{C}$ under $8 \mathrm{~h}$ of light. Seedling tissue was either frozen in liquid $\mathrm{N}_{2}$ for RNA blot analysis or was weighed and photographed after 14 days. 


\section{Preparation of boiled extracts.}

Crude boiled extracts to be tested for elicitation in the Arabidopsis seedling assay were prepared in the following manner: 500 nil of BMM $+0.2 \%$ glucose broth was inoculated with $1 \mathrm{ml}$ of bacterial culture $\left(\mathrm{OD}_{600}=0.7\right)$ and was incubated for $18 \mathrm{~h}$ (to mid-log phase) at $28^{\circ} \mathrm{C}$ in a shaker. Cultures were centrifuged at 7,000 $\times g$ for $30 \mathrm{~min}$, were washed with $200 \mathrm{ml}$ of sterile distilled water, and were recentrifuged at 7,500 $\times g$ for $30 \mathrm{~min}$. The cell pellet was resuspended in 1 to $2 \mathrm{ml}$ of sterile distilled water or $50 \mathrm{mM}$ Tris, $1 \mathrm{nM}$ EDTA, $\mathrm{pH} 7.5$, for centrifugal ultrafiltration experiments or in $4.3 \mathrm{mM} \mathrm{MES}, \mathrm{pH}$ 5.8 , for gel filtration experiments, and then, in all cases, was boiled for $10 \mathrm{~min}$. Samples were centrifuged for $10 \mathrm{~min}$ at $10,000 \times g$, and the supernatant was collected. Protein concentrations were determined using the BCA assay (Sigma) and were visualized using SDS-PAGE stained with Coomassie blue. All extracts were again boiled for $10 \mathrm{~min}$ immediately before use in seedling assays.

\section{Treatment of extracts.}

For elicitor fractionation experiments, boiled extracts were dialyzed to remove low molecular mass components using 7- or $10-\mathrm{kDa}$ molecular mass cut-off dialysis tubing (Pierce, Rockford, IL, U.S.A.). Extracts were dialyzed for $18 \mathrm{~h}$ in 2,000× volume of $d_{d d} \mathrm{H}_{2} \mathrm{O}$ with three changes of $\mathrm{ddH}_{2} \mathrm{O}$. For centrifugal ultrafiltration experiments, extracts were spun through a 5,000 molecular mass cutoff polyethersulfone membrane (Vivascience, Hanover, Germany) and, in some cases, were treated with $0.4 \%$ SDS before or after passage through the membrane, and then, dialyzed afterward using $3.5-\mathrm{kDa}$ molecular mass cutoff dialysis tubing (Pierce). These extracts were dialyzed for 24 $\mathrm{h}$ in 5,000x volume of buffer with three buffer changes. In gel filtration experiments, K60 boiled extract was separated on a calibrated Sephadex G-50 column (Amersham Biosciences, Piscataway, NJ, U.S.A.), and 1-ml fractions were collected. To remove proteins from crude boiled extracts, extracts were incubated at $37^{\circ} \mathrm{C}$ for $30 \mathrm{~min}$ with proteinase K (Sigma P-2308) at 0.006 units per $\mu \mathrm{g}$ of extract protein or a Type IX protease preparation from Bacillus polymyxa (Sigma P-6141) at 0.005 units per $\mu \mathrm{g}$ of extract protein. In all seedling treatments, except as noted, $45 \mu \mathrm{g}$ of crude boiled extract or an aliquot of a fractionated extract representing approximately $45 \mu \mathrm{g}$ of original extract were placed in each well.

\section{Tobacco response \\ to crude cellular extracts and live bacteria.}

The response of tobacco to crude boiled extracts or to live bacteria was determined by infusing the apoplastic space of 8week-old leaves (N. tabacum cv. Bottom Special) with fullstrength crude boiled extracts $(500 \mu \mathrm{g}$ of protein per $\mathrm{ml}), 10$ fold dilutions of extracts $(50 \mu \mathrm{g} / \mathrm{ml})$, or washed live bacterial suspensions $\left(1 \times 10^{7} \mathrm{CFU} / \mathrm{ml}\right)$. The infused leaf areas were observed for development of chlorosis and necrosis over a period of 4 to 5 days.

\section{Oligopeptides.}

The flg-22 oligopeptide (QRLSTGSRINSAKDDAAGLQIA) (Felix et al. 1999) was synthesized at Commonwealth Biotechnology (Richmond, VA, U.S.A.). Sequence of the $R$. solanacearum $\mathrm{K} 60 \mathrm{fliC}$ (flagellin) is available through GenBank accession number AF283285 (Tans-Kersten et al. 2001). R. solanacearum flg-22 oligopeptide (QRLSTGMRVNSAQDDAAAYASA) was synthesized at PeptideXpress (Dublin, OH, U.S.A.).

\section{RT-PCR analysis.}

Whole seedlings were harvested and frozen in liquid $\mathrm{N}_{2}$. Total RNA was extracted from seedlings using TRIzol Reagent
(Invitrogen, Carlsbad, CA, U.S.A.). Briefly, seedlings were ground in liquid $\mathrm{N}_{2}$, and tissue $(<100 \mathrm{mg}$ ) was resuspended in $1 \mathrm{ml}$ TRIzol and was extracted using published protocol. cDNA was synthesized using the First-Strand cDNA synthesis kit (Invitrogen). A $1 / 10$ fraction of the RT reaction was used as template for PCR reactions performed with Taq polymerase (Promega, Madison, WI, U.S.A.) for 40 cycles at $51^{\circ} \mathrm{C}$. PCR amplifications were performed using the following primers: PR-1 primers, 5'GTAGGTGCTCTTGTTCTTCCC $3^{\prime}$ and $5^{\prime} \mathrm{CA}$ CATAATTCCCACGAGGATC3'; ACT2 primers, 5'AGGTTC TGTTCCAGCCATC and 5'TTAGAAGCATTTCCTGTGAAC. The PCR products were separated by gel electrophoresis and were strained with ethidium bromide.

\section{Virulence assays.}

To measure the virulence of $R$. solanacearum strains on Arabidopsis Col-0 or fls2-101 plants, bacteria were grown overnight in CPG broth with appropriate antibiotics to mid$\log$ phase, were centrifuged at $6,000 \times g$ for $20 \mathrm{~min}$, were washed with distilled water, and then, the cells were resuspended in distilled water and were diluted to an $\mathrm{OD}_{600}$ approximately 1.0 , corresponding to approximately $1 \times 10^{9}$ $\mathrm{CFU} / \mathrm{ml}$. Actual concentrations applied to plants in the three experiments were $2.4 \times 10^{8}$ to $9.6 \times 10^{8} \mathrm{CPU} / \mathrm{ml}$. Three- to four-week-old Arabidopsis plants were grown in Sunshine Mix \#1 (SunGro Horticulture, Bellevue, WA, U.S.A.) in approximately 5 -cm square pots at $22^{\circ} \mathrm{C}$ with an 8 -h day. Plants were inoculated by wounding the roots with a small serrated knife without uprooting them, and then, $10 \mathrm{ml}$ of bacterial suspension $\left(1 \times 10^{10}\right.$ total cells $)$ were poured on the soil surface. Plants were coded and rated daily for 20 days by a rater blind to treatment identity, using a disease index scale of 0 to $4(0=$ no symptoms: $1=$ one to three inverted leaves or visible anthocyanin production, or both; $2=$ more than three inverted leaves and anthocyanin production; $3=$ plant wilting over less than $50 \%$ of leaf surface; and $4=$ more than $50 \%$ of leaf surfaces wilted or dead).

\section{ACKNOWLEDGMENTS}

We thank C. Boucher and S. Genin (INRA, Toulouse, France) and T. Denny (University of Georgia, Athens) for mutant strains of $R$. solanacearum. We thank A. Charkowski and S. Hirano for critical reading of the manuscript. C Pfund was a Department of Energy (DOE)-Energy Biosciences Research Fellow of the Life Sciences Research Foundation. Funding was also provided by DOE grant DE-FG02-02ER15342 to A. Bent, by National Science Foundation grant IBN 0090692 to C. Allen and J. TansKersten, and by the University of Wisconsin College of Agricultural and Life Sciences, Madison, WI, U.S.A.

\section{LITERATURE CITED}

Aderem, A. 2001. Role of toll-like receptors in inflammatory response in macrophages. Crit. Care Med 29:S16-18.

Allen, C., Huang, Y., and Sequeira, L. 1991. Cloning of genes affecting polygalacturonase production in Pseudomonas solanacearum. Mol. Plant-Microbe Interact. 4:147-154

Allen, C., Gay, J., and Simon-Buela, L. 1997. A regulatory locus, pehSR, controls polygalacturonase production and other virulence functions in Ralstonia solanacearum. Mol. Plant-Microbe Interact. 10:1054-1064.

Alonso, J. M., Stepanova, A. N., Leisse, T. J., Kim, C. J., Chen, H., Shinn, P., Stevenson, D. K., Zimmerman, J., Barajas, P., Cheuk, R., Gadrinab, C., Heller, C., Jeske, A., Koesema, E., Meyers, C. C., Parker, H., Prednis, L., Ansari, Y., Choy, N., Deen, H., Geralt, M., Hazari, N., Hom, E., Karnes, M., Mulholland, C., Ndubaku, R., Schmidt, I., Guzman, P., Aguilar-Henonin, L., Schmid, M., Weigel, D., Carter, D. E., Marchand, T., Risseeuw, E., Brogden, D., Zeko, A., Crosby, W. L., Berry, C. C., and Ecker, J. R. 2003. Genome-wide insertional mutagenesis of Arabidopsis thaliana. Science 301:653-7.

Asai, T., Tena, G., Plotnikova, J., Willmann, M. R., Chiu, W. L., GomezGomez, L., Boller, T., Ausubel, F. M., and Sheen, J. 2002. MAP 
kinase signaling cascade in Arabidopsis innate immunity. Nature 415:977-983.

Ausubel, F., Brent, R., Kingston, R., Moore, D., Seidman, J., Smith, J., and Struhl, K. 1995. Short Protocols in Molecular Biology. John Wiley and Sons, New York.

Baker, C. J., and Orlandi, E. W. 1995. Active oxygen in plant pathogenesis. Annu. Rev. Phytopathol. 33:299-322.

Bauer, Z., Gomez-Gomez, L., Boller, T., and Felix, G. 2001. Sensitivity of different ecotypes and mutants of Arabidopsis thaliana toward the bacterial elicitor flagellin correlates with the presence of receptor-binding sites. J. Biol. Chem. 276:45669-45676.

Boucher, C., Barberis, P., Trigalet, A., and Demery, D. 1985. Transposon mutagenesis of Pseudomonas solanacearum: Isolation of Tn5-induced avirulent mutants. J. Gen. Microbiol. 131:2449-2457.

Bowling, S. A., Guo, A., Cao, H., Gordon, A. S., Klessig, D. F., and Dong, X. 1994. A mutation in Arabidopsis that leads to constitutive expression of systemic acquired resistance. Plant Cell 6:1845-1857.

Brumbley, S. M., Carney, B. F., and Denny, T. P. 1993. Phenotype conversion in Pseudomonas solanacearum due to spontaneous inactivation of phcA, a putative lysR transcriptional regulator. J. Bacteriol. 175:54775487.

Chatterjee, A., Cui, Y., Liu, Y., Dumenyo, C. K., and Chatterjee, A. K. 1995. Inactivation of rsmA leads to overproduction of extracellular pectinases, cellulases, and proteases in Erwinia carotovora subsp. carotovora in the absence of the starvation/cell density-sensing signal, N-3oxohexanoyl-L-homoserine lactone. Appl. Environ. Microbiol. 161:1959-1967.

Che, F. S., Nakajima, Y., Tanaka, N., Iwano, M., Yoshida, T., Takayama, S., Kadota, I., and Isogai, A. 2000. Flagellin from an incompatible strain of Pseudomonas avenae induces a resistance response in cultured rice cells. J. Biol. Chem. 275:32347-32356.

Clarke, J. D., Liu, Y., Klessig, D. F., and Dong, X. 1998. Uncoupling PR gene expression from NPR1 and bacterial resistance: Characterization of the dominant Arabidopsis cpr6-1 mutant. Plant Cell 10:557-569.

Clough, S. J., and Bent, A. F. 1998. Floral dip: A simplified method for Agrobacterium-mediated transformation of Arabidopsis thaliana. Plant J. 16:735-743.

Dangl, J. L., and Jones, J. D. G. 2001. Plant pathogens and integrated defence responses to infection. Nature 411:826-833.

Darvill, A.G., and Albersheim, P. 1984. Phytoalexins and their elicitorsA defense against microbial infection in plants. Ann. Rev. Plant Physiol. 35:243-275.

Denny, T. 2000. Ralstonia solanacearum-A plant pathogen in touch with its host. Trend Microbiol. 11:486-489

Deslandes, L., Olivier, J., Theulieres, F., Hirsch, J., Feng, D. X., BittnerEddy, P., Beynon, J., and Marco, Y. 2002. Resistance to Ralstonia solanacearum in Arabidopsis thaliana is conferred by the recessive $R R S 1-R$ gene, a member of a novel family of resistance genes. Proc Natl. Acad. Sci. U.S.A. 99:2404-2409.

Doke, N. 1983. Generation of superoxide anion by potato tuber protoplasts during the hypersensitive response to hyphal wall components of Phytophthora infestans and specific inhibition of the reaction by suppressors of hypersensitivity. Physiol. Plant Pathol. 23:359-367.

Donnelly, M. A., and Steiner, T. S. 2002. Two nonadjacent regions in enteroaggregative Escherichia coli flagellin are required for activation of toll-like receptor 5. J. Biol. Chem. 277:40456-40461.

Ebel, J., and Scheel, D. 1997. Signals in host-parasite interactions. Pages 85-105 in: The Mycota; Vol. V, Plant Relationships, Part A. B. C. Carroll and P. Tudzynski, eds. Springer-Verlag, Berlin.

Felix, G., and Boller, T. 2003. Molecular sensing of bacteria in plants. The highly conserved RNA-binding motif RNP-1 of bacterial cold shock proteins is recognized as an elicitor signal in tobacco. J. Biol. Chem. 278:6201-6208.

Felix, G., Duran, J. D., Volko, S., and Boller, T. 1999. Plants have a sensitive perception system for the most conserved domain of bacterial flagellin. Plant J. 18:265-276.

Genin, S., Gough, C. L., Zischek, C., and Boucher, C. A. 1992. The hrp B gene encodes a positive regulator of pathogenicity genes from Pseudomonas solanacearum. Mol. Microbiol. 6:3065.

Giron, J. A., Torres, A. G., Freer, E., and Kaper, J. B. 2002. The flagella of enteropathic Escherichia coli mediate adherence to epithelial cells. Mol. Micro. 44:361-379.

Gomez-Gomez, L., and Boller, T. 2000. FLS2: An LRR receptor-like kinase involved in the perception of the bacterial elicitor flagellin in Arabidopsis. Mol Cell 5:1003-1011.

Gomez-Gomez, L., and Boller, T. 2002. Flagellin perception: A paradigm for innate immunity. Trends Plant Sci. 7:251-256.

Gomez-Gomez, L., Felix, G., and Boller, T. 1999. A single locus determines sensitivity to bacterial flagellin in Arabidopsis thaliana. Plant J. $18: 277-284$
Gomez-Gomez, L., Bauer, Z., and Boller, T. 2001. Both the extracellular leucine-rich repeat domain and kinase activity of fls2 are required for flagellin binding and signaling in Arabidopsis. Plant Cell 13:11551163

Greenberg, J. T., and Ausubel, F. M. 1993. Arabidopsis mutants compromised for the control of cellular damage during pathogenesis and aging. Plant J. 4:327-341.

Hahn, M. G. 1996. Microbial elicitors and their receptors in plants. Annu. Rev. Phytopathol. 34:387-412.

Hanahan, D. 1983. Studies on transformation of Escherichia coli with plasmids. J. Mol. Biol. 166:557-580.

Hayashi, F., Smith, K. D., Ozinsky, A., Hawn, T. R., Yi, E. C., Goodlett, D. R., Eng, J. K., Akira, S., Underhill, D. M., and Aderem, A. 2001. The innate immune response to bacterial flagellin is mediated by tolllike receptor 5. Nature 410:1099-1103.

Hayward, A. C. 1991. Biology and epidemiology of bacterial wilt caused by Pseudomonas solanacearum. Annu. Rev. Phytopathol. 29:65-87.

He, S.-Y., Huang, H.-C., and Collmer, A. 1993. Pseudomonas syringae pv. syringae harpin-Pss: A protein that is secreted via the hrp pathway and elicits the hypersensitive response in plants. Cell 73:1255-1266.

Hendrick, C., and Sequeira, L. 1984. Lipopolysaccharide-defective mutants of the wilt pathogen Pseudomonas solanacearum. Appl. Environ. Microbiol. 48:94-101.

Huang, Q., and Allen, C. 1997. An exo-poly- $\alpha$-D-galacturonosidase, PehB, is required for wild-type virulence in Ralstonia solanacearum. J. Bacteriol. 179:7369-7378.

Imler, J. L., and Hoffmann, J. A. 2001. Toll receptors in innate immunity. Trends Cell Biol. 11:304-311.

Jacchieri, S. G., Torquato, R., and Brentani, R. R. 2003. Structural study for binding flagellin by toll-like receptor 5. J. Bacteriol. 185:424-4247.

Kang, Y., Huang, J., Mao, G., He, L., and Schell, M. A. 1994. Dramatically reduced virulence of mutants of Pseudomonas solanacearum defective in export of extracellular proteins across the outer membrane. Mol. Plant-Microbe Interact. 7:370-377.

Kelman, A. 1954. The relationship of pathogenicity of Pseudomonas solanacearum to colony appearance in a tetrazolium medium. Phytopathology 44:693-695.

Khush, R. S., and Lemaitre, B. 2000. Genes that fight infection: What the Drosophila genome says about animal immunity. Trends Genet. 16:442-449.

Kopp, E., and Ghosh, S. 1994. Inhibition of NF- $\kappa$ B by sodium salicylate and aspirin. Science 265:956-959.

MacNab, R. M. 1996. Flagella and motility. Pages 123-145 in: Escherichia coli and Salmonella: Cellular and Molecular Biology. F. C. Niedhardt, ed. American Society for Microbiology Press, Washington D.C.

Maleck, K., Neuenschwander, U., Cade, R. M., Dietrich, R. A., Dangl, J. L., and Ryals, J. A. 2002. Isolation and characterization of broad-spectrum disease-resistant Arabidopsis mutants. Genetics 160:1661-1667.

Medzhitov, R., Janeway, C. A., Jr. 2002. Decoding the patterns of self and nonself by the innate immune system. Science 296:298-300.

Moens, S., and Vanderleyden, J. 1996. Functions of bacterial flagella. Crit. Rev. Microbiol. 22:67-100.

Nuhse, T. S., Peck, S. C., Hirt, H., and Boller, T. 2000. Microbial elicitors induce activation and dual phosphorylation of the Arabidopsis thaliana MAPK 6. J. Biol. Chem. 275:7521-7526.

Nurnberger, T., and Brunner, F. 2002. Innate immunity in plants and animals: Emerging parallels between the recognition of general elicitors and pathogen-associated molecular patterns. Curr. Opin. Plant Biol. 5:318-324.

Ottemann, K. M., and Lowenthal, A. C. 2002. Helicobacter pylori uses motility for initial colonization and to attain robust infection. Infect Immun. 70:1984-1990.

Petersen, M., Brodersen, P., Naested, H., Andreasson, E., Lindhart, U., Johansen, B., Nielsen, H. B., Lacy, M., Austin, M. J., Parker, J. E. Sharma, S. B., Klessig, D. F., Martienssen, R., Mattsson, O., Jensen, A B., and Mundy, J. 2000. Arabidopsis MAP kinase 4 negatively regulates systemic acquired resistance. Cell 103:1111-1120.

Scheel, D., and Parker, J. E. 1990. Elicitor recognition and signal transduction in plant defense gene activation. Z Naturforsch [C] 45:569-575.

Schuster, S. C., and Khan, S. 1994. The bacterial flagellar motor. Annu. Rev. Biophys. Biomol. Struct. 23:509-539.

Sieling, P. A., and Modlin, R. L. 2002. Toll-like receptors: Mammalian "taste receptors" for a smorgasbord of microbial invaders. Curr. Opin. Microbiol. 5:70-75.

Smith, K. D., and Ozinsky, A. 2002. Toll-like receptor-5 and the innate immune response to bacterial flagellin. Curr. Top. Microbiol. Immunol. 270:93-108.

Taguchi, F., Shimizu, R., Inagaki, Y., Toyoda, K., Shiraishi, T., and Ichinose, Y. 2003. Post-translational modification of flagellin deter- 
mines the specificity of HR induction. Plant Cell Physiol. 44:342349

Tananka, N., Che, F.-S., Watanabe, N., Fujiwara, S., Takayama, S., and Isogai, A. 2003. Flagellin from an Incompatible strain of Acidovorax avenae mediates $\mathrm{H}_{2} \mathrm{O}_{2}$ generation accompanying hypersensitive cell death and expression of $P A L, C h t-1$, and $P B Z 1$ but not of $L O X$ in rice. Mol. Plant-Microbe Interact. 16:422-428.

Tans-Kersten, J., Huang, H., and Allen, C. 2001. Ralstonia solanacearum needs motility for invasive virulence on tomato. J. Bacteriol. 183:35973065 .

Tomich, M., Herfst, C. A., Golden, J. W., and Mohr, C. D. 2002. Role of flagella in host cell invasion by Burkholderia cepacia. Infect. Immun. 70:1799-1806.

Wei, Z. M., Laby, R. J., Zumoff, C. H., Bauer, D. W., He, S. Y., Collmer, A., and Beer, S. V. 1992. Harpin, elicitor of the hypersensitive response produced by the plant pathogen Erwinia amylovora. Science 257:85-88.

Wilson, D. R., and Beveridge, T. J. 1993. Bacterial flagellar filaments and their component flagellins. Can. J. Microbiol. 39:451-472.

Young, G. M., Badger, J. L., and Miller, V. L. 2000. Motility is required to initiate host cell invasion by Yersinia entercolitica. Infect. Immun. 68:4323-4326

Yu, I.-c., Parker, J., and Bent, A. F. 1998. Gene-for-gene disease resistance without the hypersensitive response in Arabidopsis dndl mutant. Proc. Natl. Acad. Sci. U.S.A. 95:7819-7824.

AUTHOR-RECOMMENDED INTERNET RESOURCE

INRA Bioinformatique Ralstonia solanacearum webpage: sequence.toulouse.inra.fr/ralsto/Complete/doc/Complete.html

\section{Erratum}

A correction was made to this article on August 9, 2005. The flg-22 oligopeptide sequence shown on page 704 contained a typographical error that has now been corrected. 